\title{
Radon Concentrations Measurement in Dwellings of Kufa Technical Institute, Iraq Using LR-115 Nuclear Track Detector
}

Ali Abid Abojassim* and Afnan Ali Husain

Department of Physics, Faculty of Science, University of Kufa, Al-Najaf/ Kufa, box (221) Najaf, Iraq

\begin{abstract}
In this work, radon concentrations were measured in dwellings Kufa Technical institute, Iraq between November 2014 to February 2015 using time integrated passive radon dosimeters containing LR-115 Type II plastic track detectors. Also, we calculated the concentration of short-lived radon daughters, potential alpha energy, working level month, the annual effective dose rate, the annual equivalent dose rate and the excess lifetime cancer risk in all dwellings under study. The radon concentration in these dwelling ranges from $(15.211 \pm 2.745$ to $32.445 \pm 09.200)$ $\mathrm{Bq} / \mathrm{m} 3$ with an average of $(21.567 \mathrm{~Bq} / \mathrm{m} 3)$, which within the acceptable radon levels $(50-150) \mathrm{Bq} / \mathrm{m} 3 \mathrm{recommended}$ by the International Commission on Radiological Protection (ICRP). The mean the excess lifetime cancer risk were found to be ranges from 35.458 to 75.633 with an average value of 50.297 per 106 persons. These values are within in the safe limits recommended by the international organizations.
\end{abstract}

Keywords: LR-115 Type II detector; Indoor radon concentration; Lung cancer; Annual effective dose; Kufa Technical institute

\section{Introduction}

Radon is a unique natural element being found as a gas, noble, and radioactive in all of its isotopes. As gases, the isotopes are mobile and carry messages over significant distances, within the earth and in the atmosphere, but on the other side of the coin, inhalation can be a problem to one's health. The fact that radon is noble ensures that it is not immobilized by chemically reacting [1]. The decay of radon begins with uranium-238 and goes through four intermediate states to form radium-226, which has a half-life of 1,600 years. Radium-226 then decays to form radon-222 gas. Radon's half-life, 3.8 days, which provides sufficient time for it diffuse through soil and into homes, where it further disintegrates to produce the more radiologically active radon progeny ("radon daughters") [2].

The Health effects of radon, most notably lung cancer, have been investigated for several decades. Initially, investigations focused on underground miners exposed to high concentrations of radon in their occupational environment. However, in the early 1980s, several surveys of radon concentrations in homes and other buildings were carried out, and the results of these surveys, together with risk estimates based on the studies of mine workers, provided indirect evidence that radon may be an important cause of lung cancer in the general population. Recently, efforts to directly investigate the association between indoor radon and lung cancer have provided convincing evidence of increased lung cancer risk causally associated with radon, even at levels commonly found in buildings. Risk assessment for radon both in mines and in residential settings have provided clear insights into the health risks due to radon. Radon is now recognized as the second most important cause of lung cancer after smoking in the general population $[2,3]$.

Since radon is constantly escaping from the ground, it is always present in the air, but under certain circumstances the concentration of radon in a building can be increased significantly over its normal outdoor level [4]. Most buildings have a confined air space with limited air movement and only a slow exchange with outside air. Consequently the concentration of any particulates or gases released into the building atmosphere will tend to increase above the concentration normally found in outside air. Radon can enter a building in a number of ways and once inside, the concentration of its particulate progeny will increase as the radon decays. Thus, high concentrations of radon gas in soils with high transport efficiency (i.e. loose, porous, dry soil) can lead to elevated radon concentrations in buildings $[2,5]$.

Measurement of indoor radon is rather important because the radiation dose to human constitutes more than $60 \%$ of the total dose, including that from the natural sources [6]. Several techniques have been used to measure radon and are daughters concentration. LR-115 Nuclear Track Detector has been widely used for the measurement of time integrated radon levels in dwellings under different conditions [7-12].

The aim of the present work is to measure the indoor radon concentration and the annual effective dose in the Kufa technical Institute building of Kufa city by using SSNTDs technique LR-115 because there is no studying of radon concentration in this Institute.

\section{Study area}

Kufa city in Iraq, about 170 kilometres $(110 \mathrm{mi})$ south of Baghdad, and 10 kilometres $(6.2 \mathrm{mi})$ northeast of Najaf. It is located on the banks of the Euphrates River, with location of latitude $\left(32^{\circ} 1^{\prime} 46^{\prime \prime} \mathrm{N}\right)$, and longitude $\left(44^{\circ} 23^{\prime} 53^{\prime \prime} \mathrm{E}\right)$. It is located about 30 meters above the sea level, with a total area of nearly $28,824 \mathrm{~km}^{2}$ and a population of nearly 110,000 [13].

Kufa city has a desert climate characterized by extreme heat during the day, an abrupt drop in temperature at night, and slight, erratic rainfall. The weather in kufa city is dry and hot in summer; cold and less rainy in winter. Temperature is moderate in winter at $18^{\circ} \mathrm{C}$ and $42^{\circ} \mathrm{C}$ in summer. Najaf does not have a seaport. Its lands are flat and leveled in areas linked to waters from the Euphrates River and higher in the southern portions of the desert areas, extending to the republic of Iraq [13,14]. The dwelling of Kufa Technical institute were built

*Corresponding author: Ali Abid Abojassim, Department of Physics, Faculty of Science, University of Kufa, Al-Najaf/ Kufa, box (221) Najaf, Iraq, Tel: 07809644332; E-mail: ali.alhameedawi@uokufa.edu.iq

Received July 07, 2015; Accepted July 27, 2015; Published July 30, 2015

Citation: Abojassim AA, Husain AA (2015) Radon Concentrations Measurement in Dwellings of Kufa Technical Institute, Iraq Using LR-115 Nuclear Track Detector. J Nucl Med Radiat Ther S7:001. doi:10.4172/2155-9619.S7-001

Copyright: ( 2012 Abojassim AA. This is an open-access article distributed under the terms of the Creative Commons Attribution License, which permits unrestricted use, distribution, and reproduction in any medium, provided the original author and source are credited. 
Citation: Abojassim AA, Husain AA (2015) Radon Concentrations Measurement in Dwellings of Kufa Technical Institute, Iraq Using LR-115 Nuclear Track Detector. J Nucl Med Radiat Ther S7:001. doi:10.4172/2155-9619.S7-001

Page 2 of 6

using different materials, such as cement, sand stones and bricks, iron structure, marble, and concrete. Several of these materials contribute significantly to indoor radon emission. We put tracks of LR-115 detector in living which has been measuring about $7 \mathrm{~m} \mathrm{x} 4 \mathrm{~m} \mathrm{x} 4 \mathrm{~m}$, with one window and one door.

In this study we calculated the radon concentration for dwellings in Kufa Technical institute which are divided in to eight region as shown in Figure 1. Table 1 showed the sites of measurement in studied area for taking samples.

\section{Martials and Methods}

\section{Methodology}

Thirty one dosimeters, were prepared and distributed inside the underground levels of the dwellings in Kufa Technical institute. These locations are chosen to be representative of the whole region. Experimental methods for radon detection and measurements are based on alpha-counting of radon and its daughters. The plastic track detector (LR-115 type II) is a cellulose nitrate film of $12 \mu \mathrm{m}$ thickness manufacture by Kodak Path, France. Due to its ruggedness and a fine window for recording alpha particles emanating from radon progeny, it is highly useful for integrated measurements from few days to several months [15]. These plastics films of size $1 \mathrm{~cm} \mathrm{x} 1 \mathrm{~cm}$ were hung in the ceiling at distance $1 \mathrm{~m}$ above the earth of room. After the exposure period of 120 days, the detectors were etched for 120 minutes in $2.5 \mathrm{~N}$ $\mathrm{NaOH}$ solution maintained at $60^{\circ} \mathrm{C}$. The etched detectors were washed with distilled water and finally dried in air and count the number of tracks by the track counting technique, which was performed using an optical microscope. The calibration factor for dosimeters exposed for range from (4-28) day to Radium ${ }^{226} \mathrm{Ra}$ (Radon source) of activity 3.3 $\mathrm{kBq}$ was calculated to be $(0.0216 \pm 0.0033)$ [(Bq.d. $\left.\mathrm{m}^{-3}\right)$ per (track.cm $\left.{ }^{2}\right)$. The value is approximately the same as that reported in many works [15-17].

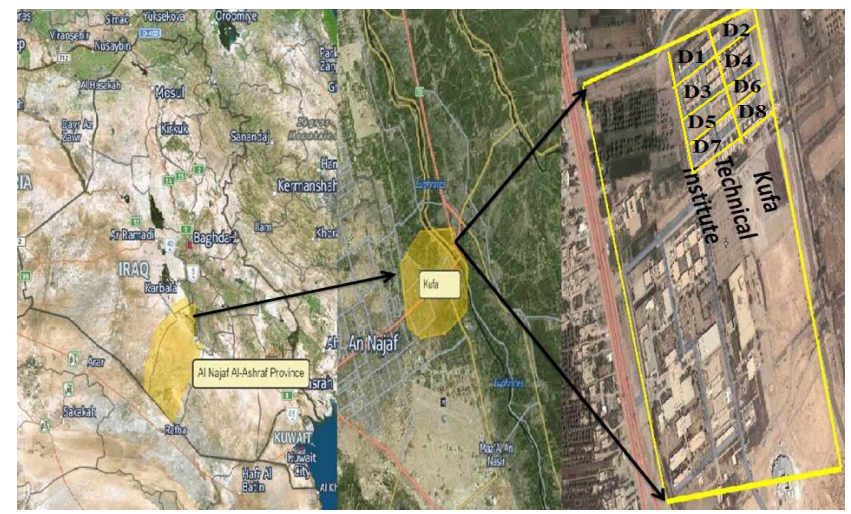

Figure 1: Kufa Technical institute.

\section{Measurement of radon concentration}

The tracks density is measured by using equation (1) [18]:

$$
\text { Track density }\left(\frac{\text { track }}{\mathrm{cm}^{2}}\right)=\frac{\text { Average number of total tracks }}{\text { view field of Area }} \text {..... }
$$

Radon concentrations $\left(\mathrm{C}_{\mathrm{Rn}}\right)$ in present work are determined by the equation [19-21]:

$$
\begin{aligned}
& C_{R n}\left(\frac{B q}{m^{3}}\right)=\frac{C_{0}\left(B q \cdot d a y / m^{3}\right)}{\rho_{o\left(\frac{\text { rack }}{\mathrm{cm}^{2}}\right)}} \frac{\rho_{\left(\frac{\text { track }}{\mathrm{cm}^{2}}\right)}}{t(\text { day })} \\
& \frac{C_{0}\left(B q \cdot d a y / \mathrm{m}^{3}\right)}{\rho_{o\left(\frac{\text { track }}{\mathrm{cm}^{2}}\right)}} \text { is calibration factor for dosimeters exposed (it gives }
\end{aligned}
$$

$(0.0216 \pm 0.0033)\left[\left(\right.\right.$ Bq.day $\left.\left./ \mathrm{m}^{3}\right) \operatorname{per}\left(\operatorname{track} / \mathrm{cm}^{2}\right)\right]$.

$\rho=$ track density (number of tracks $/ \mathrm{cm}^{2}$ ) of distributed detectors,

$\mathrm{t}=$ exposure time (days) of distributed detectors.

\section{Calculation of EEC, PAE and WLM}

The track density on the detector is related to the potential alpha energy (PAE) concentration expressed in Working Level (WL) units. WL is the concentration of any combination of radon progeny corresponds to $1.3 \times 10^{5} \mathrm{MeV}$ of PAE per liter of air [22]. The resulting concentration of short-lived radon daughters expressed in term of an equilibrium-equivalent radon concentration (EEC), is related to the activity concentration of radon $\left(\mathrm{C}_{\mathrm{Rn}}\right)$ by the equation (3) $[22,23]$ :

$$
\operatorname{EEC}\left(\frac{B q}{}\right)=C_{R n} \times F
$$
[22,23].

where $\mathrm{F}$ is an equilibrium factor which is equal 0.4 in indoor air

The Potential Alpha Energy (PAE) concentration calculated in $\mathrm{mWL}$ using equation (4) [22]:

$$
P A E(m W L)=\frac{E E C}{3700}
$$

Exposure to indoor ${ }^{222} \mathrm{Rn}$ in terms of working level month (WLM) for indoor has been calculated using the following equation:

$$
W L M=W L \frac{8760}{170}
$$

\section{Estimated the Excess Lifetime Cancer Risk (ELCR)}

Indoor radon has been determined to be the second leading cause of lung cancer after tobacco smoking [24]. Radon effective dose value describes the harmful effects of radon on the human body; therefore, it is necessity to calculate the radon dose from radon concentration. There are large uncertainties in dosimetric assessments and epidemiological

\begin{tabular}{|c|c|c|c|c|c|c|}
\hline \multirow{2}{*}{ No. } & \multirow{2}{*}{ Location Symbol } & \multicolumn{2}{|c|}{ Number of Track } & \multicolumn{2}{|c|}{ Coordinates } \\
\cline { 3 - 6 } & distributed & collected & Lat.(deg) & Long. (deg) \\
\hline 1 & D1 & 4 & 4 & 32.061271 & 44.404522 \\
\hline 2 & D2 & 4 & 4 & 32.061521 & 4.405205 \\
\hline 3 & D3 & 4 & 4 & 32.061754 & 44.405899 \\
\hline 4 & D4 & 4 & 4 & 32.060883 & 44.404706 & $26-25$ \\
\hline 5 & D5 & 4 & 4 & 32.061088 & 44.405394 \\
\hline 6 & D6 & 4 & 4 & 32.061310 & 44.406121 \\
\hline 8 & D7 & 4 & 4 & 32.060628 & 44.405618 \\
\hline
\end{tabular}

Table 1: Sites of measurements in studied area for taking samples. 
aspects for the conversion of a radon exposure to a radon dose [25]. We used UNSCEAR's radon dose conversion factor as it lies between dosimetric and epidemiological dose conversions [26,27]. UNSCEAR suggests that in estimating the effective doses, the following factors are applied [28]:

- An indoor radon decay product equilibrium factor of $E_{\mathrm{f}}=0.4$

- A radon effective dose coefficient factor of $\mathrm{C}_{\mathrm{f}}=9 \mathrm{nSv} /\left(\mathrm{Bq} \mathrm{h} \mathrm{m}^{-3}\right)$

- An indoor occupancy factor of $\mathrm{O}_{\mathrm{f}}=0.8$, which is the fraction time that people spend indoors, but not essentially in their homes. It means, during one year $(T=365 \times 24 \mathrm{~h})$, people spend about $8,760 \mathrm{~h}$ at indoor spaces like home and office.

So, the equation for annual absorption dose $\left(D_{R n}\right)$ due to radon concentration is:

$$
D_{R n}\left(\frac{m S v}{y}\right)=E_{f} \times C_{f} \times O_{f} \times C_{R n} \times T
$$

where $\mathrm{C}_{\mathrm{Rn}}$ is the radon concentration in $\mathrm{Bq} / \mathrm{m}^{3}$ scale. By using this equation, annual radon effective dose has been calculated.

In the biological effect of radiation, to calculate the annual equivalent dose, two types of weighting factors are needed in order to estimate the level dose. A radiation weighting factor and a tissue weighting factor. The radiation weighting factor $\left(\mathrm{W}_{\mathrm{R}}\right)$ for alpha particles is 20 as recommended by ICRP [29] and a tissue weighting factor $\left(\mathrm{W}_{\mathrm{T}}\right)$ is applied. The weighting factor that used in this study is $0.12[30,31]$. The annual equivalent dose was then calculated using the following equation [32].

$$
H_{E}\left(\frac{m S v}{y}\right)=D_{R n} \times W_{R} \times W_{T}
$$

Where $\mathrm{H}_{\mathrm{E}}(\mathrm{mSv} / \mathrm{y})$ is the annual equivalent dose, $\mathrm{D}_{\mathrm{Rn}}$ is the annual effective dose, $\mathrm{W}_{\mathrm{R}}$ is radiation weighting factor and $\mathrm{W}_{\mathrm{T}}$ is tissue weighting factor.

The excess lifetime cancer risk (ELCR) per million persons per year (MPY) was calculated using formula in Ref [33].

$$
E L C R=H_{E} \times D L \times R F
$$

Where, DL is the Duration of Life (70 y) and RF is the Risk Factor $\left(0.055 \mathrm{~Sv}^{-1}\right)$ recommended by the ICRP [29].

\section{Results and Discussions}

The minimum, maximum values and the average of radon ${ }^{222} \mathrm{Rn}$ gas concentrations for each monitored dwelling is reported in Table 2. The average radon concentration in dwellings was $21.567 \mathrm{~Bq} / \mathrm{m}^{3}$, this variation in radon concentration is fundamental related with type of construction and age of the building, the minimum and maximum values for indoor radon concentration were found in sample (T10) and sample (T19) which equal to $15.211 \pm 2.745 \mathrm{~Bq} / \mathrm{m}^{3}$ and $32.445 \pm 09.200$ $\mathrm{Bq} / \mathrm{m}^{3}$ respectively. The variable from one region to another due to different concentration of uranium in different regions, these results are within the radon levels $(50-150) \mathrm{Bq} / \mathrm{m}^{3}$ which are recommended by ICRP [34]. The values of equilibrium equivalent concentration (EEC), potential alpha energy (PAE) and monthly work level (MWL) of the study area are given in Table 3 . The average values of equilibrium equivalent concentration, potential alpha energy concentration and monthly work level for each of the 31 samples were $8.630 \mathrm{~Bq} / \mathrm{m}^{3}$,

\begin{tabular}{|c|c|c|c|c|}
\hline \multirow{2}{*}{ No. } & \multirow{2}{*}{ Sample Code } & \multicolumn{3}{|c|}{ Radon Concentrations (Bq/m³) } \\
\hline & & Minimum & Maximum & Average \pm S.D \\
\hline 1 & T1 & 20.131 & 28.296 & $23.545 \pm 3.850$ \\
\hline 2 & $\mathrm{~T} 2$ & 18.664 & 23.417 & $20.308 \pm 6.976$ \\
\hline 3 & T3 & 15.784 & 23.964 & $19.655 \pm 11.303$ \\
\hline 4 & $\mathrm{~T} 4$ & 20.491 & 26.998 & $22.266 \pm 10.001$ \\
\hline 5 & T5 & 17.027 & 24.075 & $19.608 \pm 9.9663$ \\
\hline 6 & T6 & 16.530 & 20.333 & $19.097 \pm 5.483$ \\
\hline 7 & T7 & 14.268 & 26.032 & $20.150 \pm 16.168$ \\
\hline 8 & T8 & 16.931 & 21.729 & $18.962 \pm 7.572$ \\
\hline 9 & T9 & 23.476 & 31.211 & $27.647 \pm 11.301$ \\
\hline 10 & T10 & 14.248 & 16.342 & $15.211 \pm 2.745$ \\
\hline 11 & T11 & 14.391 & 20.574 & $16.939 \pm 9.251$ \\
\hline 12 & T12 & 14.531 & 19.662 & $17.930 \pm 7.291$ \\
\hline 13 & T13 & 13.735 & 20.105 & $16.292 \pm 8.713$ \\
\hline 14 & T14 & 17.031 & 25.635 & $20.958 \pm 12.048$ \\
\hline 15 & T15 & 13.996 & 18.301 & $16.208 \pm 7.436$ \\
\hline 16 & T16 & 12.897 & 23.648 & $18.220 \pm 13.899$ \\
\hline 17 & T17 & 15.155 & 25.059 & $21.084 \pm 13.871$ \\
\hline 18 & T18 & 14.178 & 22.134 & $17.450 \pm 10.661$ \\
\hline 19 & T19 & 25.173 & 38.949 & $32.445 \pm 09.200$ \\
\hline 20 & T20 & 20.309 & 35.739 & $25.653 \pm 11.724$ \\
\hline 21 & $\mathrm{~T} 21$ & 21.139 & 29.772 & $26.859 \pm 15.024$ \\
\hline 22 & T22 & 21.981 & 39.121 & $29.845 \pm 12.392$ \\
\hline 23 & T23 & 20.000 & 27.245 & $22.924 \pm 10.048$ \\
\hline 24 & T24 & 21.015 & 23.153 & $22.140 \pm 2.818$ \\
\hline 25 & T25 & 20.686 & 23.907 & $21.799 \pm 4.587$ \\
\hline 26 & T26 & 17.793 & 24.908 & $21.635 \pm 9.461$ \\
\hline 27 & T27 & 17.715 & 26.773 & $20.442 \pm 13.424$ \\
\hline 28 & T28 & 15.444 & 31.474 & $24.983 \pm 11.724$ \\
\hline 29 & T29 & 20.326 & 26.691 & $23.209 \pm 8.329$ \\
\hline 30 & T30 & 14.347 & 29.600 & $23.519 \pm 10.633$ \\
\hline 31 & T31 & 16.602 & 26.674 & $21.888 \pm 15.11$ \\
\hline & Average & 17.6127 & 25.855 & 21.567 \\
\hline
\end{tabular}
$2.332 \mathrm{mWL}$ and 0.120 respectively. Table 4 shows the values of annual effective dose $\left(D_{R n}\right)$, annual equivalent dose $\left(H_{E}\right)$ and the excess lifetime
Table 2: Observed radon concentrations at different places in study area

cancer risk per million persons per year (ELCR). The annual effective dose, the annual equivalent dose received by the residents of the study area varied from $0.383 \mathrm{mSv} / \mathrm{y}$ to $0.818 \mathrm{mSv} / \mathrm{y}$ with an average of 0.544 $\mathrm{mSv} / \mathrm{y}$ and from $0.921 \mathrm{mSv} / \mathrm{y}$ to $1.964 \mathrm{mSv} / \mathrm{y}$ with an average of 1.306 $\mathrm{mSv} / \mathrm{y}$ respectively. The high value of the annual effective dose in this study were $(0.818) \mathrm{mSv} / \mathrm{y}$. This value was lower than the permissible limits recommended by world health organization (WHO) [35] which it is equal (1-3) $\mathrm{mSv} / \mathrm{y}$. According to ours estimations, Table 4 shows the radon induced lung cancer risk for all dwelling in Kufa Technical institute was found and ranges from 35.458 to 75.633 with an average value of 50.297 per $10^{6}$ persons. In general, these estimates indicated that the dwelling under study are characterized by low radon exposure dose, so the people who live in those dwelling are subject to relatively low risk factor for radon induced lung cancer. In general the low levels of radon concentration in these buildings can be attributed to the following reasons such as the good ventilation systems in most places and the good geometric designs, all walls are painted and most locations have covered floors and there are no cracks in the building basement.

Table 5 summarizes the comparison between our results with those conducted in other countries. It seems that our results are near or around the other results [35-44].

\section{Conclusions}

In conclusion, we found that the radon levels in Dwellings of Kufa 


\begin{tabular}{|c|c|c|c|c|}
\hline No. & Sample Code & $\operatorname{EEC}\left(\mathrm{Bq} / \mathrm{m}^{3}\right)$ & PAE (mWL) & WLM \\
\hline 1 & $\mathrm{~T} 1$ & 9.418 & 2.545 & 0.131 \\
\hline 2 & T2 & 8.123 & 2.195 & 0.113 \\
\hline 3 & T3 & 7.862 & 2.124 & 0.109 \\
\hline 4 & T4 & 8.906 & 2.407 & 0.124 \\
\hline 5 & T5 & 7.843 & 2.119 & 0.109 \\
\hline 6 & T6 & 7.638 & 2.064 & 0.106 \\
\hline 7 & $\mathrm{~T} 7$ & 8.060 & 2.178 & 0.112 \\
\hline 8 & T8 & 7.584 & 2.049 & 0.105 \\
\hline 9 & T9 & 11.058 & 2.988 & 0.154 \\
\hline 10 & T10 & 6.084 & 1.644 & 0.084 \\
\hline 11 & T11 & 6.775 & 1.831 & 0.094 \\
\hline 12 & T12 & 7.172 & 1.938 & 0.099 \\
\hline 13 & T13 & 6.516 & 1.761 & 0.091 \\
\hline 14 & T14 & 8.383 & 2.265 & 0.116 \\
\hline 15 & T15 & 6.483 & 1.752 & 0.090 \\
\hline 16 & T16 & 7.288 & 1.969 & 0.101 \\
\hline 17 & T17 & 8.433 & 2.279 & 0.117 \\
\hline 18 & T18 & 6.980 & 1.886 & 0.097 \\
\hline 19 & T19 & 12.978 & 3.507 & 0.181 \\
\hline 20 & T20 & 10.261 & 2.773 & 0.142 \\
\hline 21 & $\mathrm{~T} 21$ & 10.743 & 2.903 & 0.149 \\
\hline 22 & T22 & 11.938 & 3.226 & 0.166 \\
\hline 23 & T23 & 9.169 & 2.478 & 0.127 \\
\hline 24 & T24 & 8.856 & 2.393 & 0.123 \\
\hline 25 & T25 & 8.719 & 2.356 & 0.121 \\
\hline 26 & T26 & 8.654 & 2.338 & 0.120 \\
\hline 27 & T27 & 8.176 & 2.209 & 0.113 \\
\hline 28 & T28 & 9.993 & 2.701 & 0.139 \\
\hline 29 & T29 & 9.283 & 2.509 & 0.129 \\
\hline 30 & T30 & 9.407 & 2.542 & 0.131 \\
\hline 31 & T31 & 8.755 & 2.366 & 0.122 \\
\hline \multicolumn{2}{|r|}{ Average } & 8.630 & 2.332 & 0.120 \\
\hline
\end{tabular}

Table 3: Values of (EEC), (PAE) and (MWL) in all samples of studied area.

Technical institute are within the internationally acceptable values and there is no health risks. The average equals to (21.567) $\mathrm{Bq} / \mathrm{m}^{3}$. The averageof reading were lower than the permissible limits recommended by ICRP. Also, it is found that all radiation parameters in this study such as potential alpha energy, equilibrium-equivalent radon concentration, working level month, the annual effective dose, the annual equivalent dose rate and the excess lifetime cancer risk per million persons per year rate depend upon many factors inside the dwellings. Ventilation plays an important role as far as the problem is concerned. Computed data indicates that region is safe without posing significant radiological threat to population.

\section{References}

1. Banjanac R, Dragić A, Grabež B, Jokovic D, Markushev D, et al. (2006) In Indoor radon measurements by nuclear track detectors :applications in secondary school. Physics, chemistry technology 4: 93-100.

2. http://www.lung.org/associations/charters/midland-states/assets/pdfs/ program-misc/kentucky-radon-report.pdf.

3. http://nuclearsafety.gc.ca/pubs_catalogue/uploads/February-2011-Info-0813Radon-and-Health-INFO-0813_e.pdf.

4. NCRP National Council on Radiation Protection and Measurements (1987) Exposures of the population in the United States and Canada from natural background radiation. Bethesda, Maryland (NCRP Report No. 94).

5. Borgoni R, Tritto V, Bigliottoand C, de Bartolo D (2002) A Geostatistical Approach to Assess the Spatial Association between Indoor Radon

\begin{tabular}{|c|c|c|c|c|}
\hline No. & Sample Code & $D_{R n}(m S v / y)$ & $H_{E}(m S v / y)$ & $\operatorname{ELCR}\left(10^{-4}\right)$ \\
\hline 1 & T1 & 0.594 & 1.425 & 54.886 \\
\hline 2 & T2 & 0.512 & 1.229 & 47.340 \\
\hline 3 & T3 & 0.495 & 1.190 & 45.818 \\
\hline 4 & $\mathrm{~T} 4$ & 0.561 & 1.348 & 51.905 \\
\hline 5 & T5 & 0.494 & 1.1872 & 45.709 \\
\hline 6 & T6 & 0.481 & 1.156 & 44.517 \\
\hline 7 & $\mathrm{~T} 7$ & 0.508 & 1.220 & 46.972 \\
\hline 8 & T8 & 0.478 & 1.148 & 44.203 \\
\hline 9 & T9 & 0.697 & 1.674 & 64.449 \\
\hline 10 & T10 & 0.383 & 0.921 & 35.458 \\
\hline 11 & T11 & 0.427 & 1.025 & 39.487 \\
\hline 12 & T12 & 0.452 & 1.085 & 41.797 \\
\hline 13 & T13 & 0.411 & 0.986 & 37.978 \\
\hline 14 & T14 & 0.528 & 1.268 & 48.856 \\
\hline 15 & T15 & 0.408 & 0.981 & 37.783 \\
\hline 16 & T16 & 0.459 & 1.103 & 42.473 \\
\hline 17 & T17 & 0.531 & 1.276 & 49.149 \\
\hline 18 & T18 & 0.440 & 1.056 & 40.678 \\
\hline 19 & T19 & 0.818 & 1.964 & 75.633 \\
\hline 20 & T20 & 0.647 & 1.553 & 59.800 \\
\hline 21 & T21 & 0.677 & 1.626 & 62.612 \\
\hline 22 & T22 & 0.752 & 1.807 & 69.572 \\
\hline 23 & T23 & 0.578 & 1.388 & 53.439 \\
\hline 24 & T24 & 0.558 & 1.340 & 51.611 \\
\hline 25 & T25 & 0.549 & 1.319 & 50.816 \\
\hline 26 & T26 & 0.545 & 1.309 & 50.434 \\
\hline 27 & T27 & 0.515 & 1.237 & 47.653 \\
\hline 28 & T28 & 0.630 & 1.512 & 58.238 \\
\hline 29 & T29 & 0.585 & 1.405 & 54.103 \\
\hline 30 & T30 & 0.593 & 1.424 & 54.826 \\
\hline 31 & T31 & 0.552 & 1.325 & 51.024 \\
\hline \multicolumn{2}{|r|}{ Average } & 0.544 & 1.306 & 50.297 \\
\hline
\end{tabular}

Table 4: Values of annual effective dose, annual equivalent dose and the excess lifetime cancer risk in all samples of studied area.

\begin{tabular}{|c|c|c|}
\hline Country & Indoor radon concentration $\left.\mathbf{( B q} / \mathbf{m}^{3}\right)$ & Reference \\
\hline Saudi Arabia & $21-34$ & {$[36]$} \\
\hline Iraq & 61.2 & {$[37]$} \\
\hline Serbia & 20 & {$[38]$} \\
\hline Yemen & 42 & {$[39]$} \\
\hline Brazil & 40 & {$[40]$} \\
\hline India & $15-41$ & {$[41]$} \\
\hline Poland & 32 & {$[42]$} \\
\hline Saudi Arabia & $6-24$ & {$[43]$} \\
\hline Korea & 34.1 & {$[44]$} \\
\hline Study area & $15-32$ & ------- \\
\hline
\end{tabular}

Table 5: Comparison between our results with international studies.

Concentration, Geological Features and Building Characteristics. Int J Environ Res Public Health 8: 1420-1440.

6. UNSCEAR (1998) United Nations Scientific Committee on the Effect of Atomic Radiation. United Nations New York.

7. Pundir A, Kamboj S, Singh R (2014) Estimation of indoor Radon, Thoron and their progeny levels in some dwellings of District Yamuna Nagar of India using SSNTD”. Nature and Science 12: 94-97.

8. Al-Mosuwi WH, Subber ARH (2013) Indoor Radon Concentration in the Basra Sport City, Basra, Iraq. Journal of Basrah Researches (Sciences) 39: 150-157.

9. Verma D, Khan MS (2014) Assessment of indoor radon, thoron their progeny in dwelling of Bareilly city of northern India using track etch detectors. Rom Journ. Phys 59: 172-182. 
Citation: Abojassim AA, Husain AA (2015) Radon Concentrations Measurement in Dwellings of Kufa Technical Institute, Iraq Using LR-115 Nuclear Track Detector. J Nucl Med Radiat Ther S7:001. doi:10.4172/2155-9619.S7-001

10. Gupta M, Mahur AK, Verma KD (2012) Indoor radon levels in some dwellings surrounding the National Thermal Power Corporations (NTPCs), India Advances in Applied Science Research 3: 1262-1265.

11. Abd-Elzaher M (2012) An Overview on Studying 222Rn Exhalation Rates using Passive Technique Solid-State Nuclear Track Detectors. American Journal of Applied Sciences 9: 1653-1659

12. Singha $P$, Singha $P$, Singha S, Sahoob BK, Saprab BK, et al. (2015) A study of indoor radon, thoron and their progeny measurement in Tosham region Haryana, India. Journal of Radiation Research and Applied Sciences 8: 226233.

13. Trudy R (1996) “Najaf”. Global Security. R etrieved 2009-09-13.

14. Trudy R (1996) Najaf. Global Security.

15. Eappen KP, Mayya YS (2004) Calibration factors for LR-115 (type-II) based radon thoron discriminating dosimeter. Radiation Measurements 38: 5-17.

16. Pundir A, Kamboj S, Singh R (2014) Estimation of indoor Radon, Thoron and their progeny levels in some dwellings of District Yamuna Nagar of India using SSNTD. Nature and Science 12: 94-97.

17. Duggal V, Rani A, Mehra R (2014) A study of seasonal variations of radon levels in different types of dwellings in Sri Ganganagar district, Rajasthan. Journal of Radiation Research and Applied Sciences 7: 201-206.

18. Lymburner D (2003) Another Human Experiment. DU Education Project, Metal of Dishonor, International Action Center, NewYork, 45-98.

19. Al-Kofahi M, Khader B, Lehlooh A, Kullab M, Abumurad K, et al. (1992) Measurement of Radon-222 in Jordanian Dwellings. International Journal of Radiation Applications and Instrumentation. Part D. Nuclear Tracks and Radiation Measurements 20: 377-382.

20. Khader B (1990) Radon-222 Concentration in the Air of the Dwellings in Irbid Region- Jordan. Yarmouk Univ., Irbid M. Sc. Thesis.

21. Corporation T, Lane W, Creek W, Fleischer R (1981) Passive Integrating Radon Monitor for Environmental Monitoring. Health Phys 40: 693-702.

22. Gupta M, Mahur AK, Verma KD (2012) Indoor radon levels in some dwellings surrounding the National Thermal Power Corporations (NTPCs), India. Advances in Applied Science Research, 3: 1262-1265.

23. Khan MSA, Tariq M, Rawat RBS (2012) Preliminary Measurements of Radon Radiations in (Bare Mode) In Rampur District of Western U.P. (India). IOSR Journal of Applied Physics, 1.

24. Marley F, Denman AR, Philips PS (1998) Studies of radon and radon progeny in air conditioned rooms in hospitals. Radiation Protection Dosimetry 5: 273276

25. Chen J (2005) A review of radon doses. Radiation Protection Management 22: $27-31$.

26. WHO (2009) World Health Organization, Sets radon action level of 2.7 - less lung cancer risk than EPA 4.0. Global Press Release Distribution.

27. IARC (1988) International Agency for Research on Cancer. Summaries \& Evaluations, 43
28. UNSCEAR (2000) United Nations scientific committee on the effect of atomic radiation sources, effects and risks of ionizing radiation. New York: United Nations.

29. https://www.oecd-nea.org/rp/reports/2011/nea6920-ICRP-recommendations.pdf

30. Mossadegh N, Karimian A, Shahhosseini E, Mohammadzadeh A, Sheibani Sh (2011) Experimental simulation of personal dosimetry in production of medical radiations by research reactor. Radiat Prot Dosimetry 147: 267-271.

31. Issa $E$ (2007) Determination of the conversion factor for the estimation of effective dose in lungs, autography and cardiac procedures Thesis for Master of Science in Medical Radiation Physics.

32. Alberigi S, Pecequilo BR, Lobo HA, Campos MP (2004) Assessment of effective dose from radon levels for tour guides at several galleries of Santana cave Southern Brazil, with CR-39 Preliminary results Radiation. Radiat Prot Dosimetry 145: 252-255

33. Obed RI, Ademola AK, Ogundare FO (2011) Radon measurements by nuclea track detectors in dwelling Oke- Ogun area, South-Western, Nigeria. Radiation. Protection Dosimetry 148: 475-481.

34. ICRP (1993) Protection Against Radon-222 at Home and at Work. Ann ICRP $23(2)$.

35. WHO (2009) WHO handbook on indoor radon - a public health perspective.

36. Abu-Jarad F, Islam MA (1993) A passive radon detector survey in a three-story laboratory building. Nuclear Tracks and Radiation Measurements 22: 257-258.

37. Tawfiq NF (1996) Study Comparssion in Some of Organic and Inorganic Track Detectors and Applications in Environment. Ph.D thesis, University of Al-Mustansiriyah.

38. Antanasijević R, Aničin I, Bikit I, Banjanac R, Dragić A, et al. (1999) Radon measurements during the building of a low-level laboratory. Radiation Measurements $31: 371-374$.

39. Khayrata AH, Al-Jarallahb MI, Fazal-ur-Rehmanb X, Abu-Jaradc F (2003) Indoor radon survey in dwellings of some regions in Yemen. Radiation Measurements 36: 449-451.

40. Magalhaes MH, Amaral ECS, Sachett I, Rochedo ERR (2003) Radon-222 in Brazil: an outline of indoor and outdoor measurements. Journal of Environmental Radioactivity 67: 131-143.

41. Shaikh AN, Ramachandran TV, Vinod Kumar A (2003) Monitoring and modelling of indoor radon concentrations in a multi-storey building at Mumbai, India. J Environ Radioact 67: 15-26

42. Mnich Z, Karpińska M, Kapała J, Kozak K, Mazur J, et al. (2004) Radon concentration in hospital buildings erected during the last 40 years in Białystok, Poland. Journal of Environmental Radioactivity 75: 225-232.

43. Qahtani M, Jarallah MI, Rehman F(2005) Indoor radon measurements in the Women College, Dammam, Saudi Arabia. Radiation Measurements 40: 704706 .

44. Yoon S, Chang B, Kim Y, Byun J, Yun J (2010) Indoor radon distribution of subway stations in a Korean major city. Journal of Environmental Radioactivity 101: 304-308.
This article was originally published in a special issue, Therapeutic Nuclear Medicine handled by Editor(s). Dr. Maseeh uz Zaman, Aga Khan University Hospital (AKUH), Pakistan 